\title{
Determinants for new role of contemporary parliament
}

\author{
Haider Muthnna Almoatasm
}

Department of Economic and Politics Science, Cairo University, Giza, Egypt

\begin{abstract}
Purpose - This paper aims to scrutinize some determinants that affect the functions and roles of contemporary parliaments. In particular, such parliaments attempt to involve in new areas that were not represented in parliamentary study and to play new roles in the areas of development, diplomacy, the establishment of post-conflict peace rules and achieving the objectives of the sustainable development. The study found that the most important determinants affecting the new roles of contemporary parliaments are the constitutional and legal frameworks.
\end{abstract}

Design/methodology/approach - This paper adopts three basic methodologies so as to reach some applicable scientific findings that can be generalized. The researcher has used the descriptive methodology, to shed light on the parliament's various activities and new roles and to take note of the many surrounding factors and available dimensions that enable parliaments to perform such roles. The researcher has also used the comparative methodology, to study parliaments with a view to identifying their roles in a way that includes their similarities and dissimilarities and the possibility of generalizing the outputs.

Findings - The paper has reached many findings, the most important of which are: first, the need to present appropriate amendments to the constitutions to give space to parliaments to play more effective and influential roles. Second, the internal regulations of parliaments must be in line with the attitudes and aspirations of the parliament and its members, giving appropriate cover for playing new roles in various areas.

Research limitations/implications - This study has found that contemporary parliaments can play new roles in various fields, whether internal or external and in different sectors as well, as a result of the great developments and complexities introduced around the world. Such developments and complexities have cast a shadow on governments and affected their abilities in dealing with the issues immediately because of the enormous challenges in addition to the ongoing developments occurring to the legislative systems in the world, at the technical level of the departments and secretariats of contemporary parliaments or for members of Parliament and the institution as a whole.

Practical implications - The new roles of contemporary parliaments have been affected by the determinants of the research, which are the constitutional framework, the legislative framework, the relationship between Parliament and civil society and the relationship between Parliament and the government. These factors cast a shadow over the expansion or contraction of the attempts of modern parliaments to play new roles.

Social implications - This study has found that contemporary parliaments can play social roles in various fields of a social nature, which is find solutions to the problems experienced by societies emerging from civil wars, which need national reconciliation, for example, the reconciliation of the ethnic tribes carried out by the Iraqi council of representatives between the local tribes to resolve the internal problems, in addition the role of Borondian council by it is trying end the conflict between the tribes of Hotsi and Tutsi.

(C) Haider Muthnna Almoatasm. Published in Review of Economics and Political Science. Published by Emerald Publishing Limited. This article is published under the Creative Commons Attribution (CC BY 4.0) license. Anyone may reproduce, distribute, translate and create derivative works of this article (for both commercial and non-commercial purposes), subject to full attribution to the original publication and authors. The full terms of this license may be seen at http://creativecommons.org/ licences/by/4.0/legalcode

Received 10 June 2019 Revised 10 October 2019

31 December 2019

9 February 2020

Accepted 24 March 2020
Review of Economics and Political Science e-ISSN: 2631-3561 p-ISSN: 2356-9980 DOI 10.1108/REPS-06-2019-0083


Originality/value - The importance of the study stems from the fact that it focuses on the most important determinants of the new roles of contemporary parliaments that may be conducted outside the traditional framework of the parliament's study of legislation and supervision. Such contemporary parliaments have played new roles that take the form of political, economic, social, humanitarian, diplomatic and environmental works and other works concerned with the climate and their attempts to end internal and external conflicts and disputes.

Keywords Contemporary parliaments, New roles, Parliament's functions, Separation of powers, Parliamentary experiences

Paper type Research paper

\section{Introduction}

Parliament is the authority selected by-election, general secret ballot, appointment or inheritance. Thus, it is the supreme authority or the first authority in terms of the level (Al-Hendaoi, 2010, p. 140). It consists of a group of individuals called deputies or representatives of the people. Parliament has full authority to enact or void legislation and laws, control over the work of the executive or ratify international conventions. After the spread of the elected parliaments in the contemporary world, they became political institutions of great importance in many countries and increased their size to include two councils to perform multiple functions and roles. They sometimes bypass enacting legislations and control over the governments' actions. Thus, they affect the internal, regional and international affairs, taking into account political, economic, social and even environmental and climatic dimensions. In addition, contemporary parliaments help in expressing countries' political interests and socialization (El-Menoufi, 1987, p. 231).

The most important functions of parliament are representing the people during the process of enacting laws, discussing the state's budget and approving it and making important decisions that will determine the fate of the people such as the ratification of international conventions, membership in international organizations or declaration of war. Moreover, contemporary parliaments started to play new roles in accordance with the necessity of the countries' needs such as entering into international parliamentary coalitions to eliminate particular phenomena such as poverty, hunger, desertification and other related issues or fostering national reconciliation in countries experiencing internal conflicts. Furthermore, parliament sponsors initiatives to contain crises that may arise between governments and the people such as the Yemeni parliament's initiatives where it reached a consensus to mandate the heads of parliamentary blocs to prepare a formula of national reconciliation that would bring together political parties in the light of the current national crisis to end the conflict and internal strife following the popular revolution against the rule of Abdullah Saleh. The Yemeni rightwing parliament was retained as a representative of the people according to the constitution, which allows the parliament to remain in "state of crisis" (Yemeni Parliament Observatory, 2014). Additionally, in 2017 there have been attempts of the Sudanese parliament to achieve peaceful coexistence among the Sudanese citizens by presenting proposals to end the state of an internal war and extend the cease-fire, declaring the Sudanese parliament's rejection of selfdetermination of the two states South Kordofan and Blue Nile and urging the Sudanese government to meet the demands of residents of the regions, in particular the elimination of political and economic marginalization.

\subsection{The research problem}

The problem of the research stems from the fact that it tries to highlight new untraditional roles and functions played by contemporary parliaments, based on the two constitutional 
and procedural frameworks and enforcing laws. The research attempts to scrutinize and depicts these roles and functions, depending on the social and political weight that helps the parliament to assume such roles and missions. Besides, the course of political, social and economic events have been accelerated and complicated by virtue of globalization, casting its shadow over all works and functions of parliaments, which necessitated studying. The research also has tried to benefit from theories that created functions and tasks of parliaments and it has attempted to benefit from contemporary experiences that contribute to tackling the issues of stability, development and social cohesion. Thus, the research problem revolves around the following question:

Q1. What are the new roles and functions undertaken by contemporary parliaments around the world?

This leads to the attempt of knowing the impact of the two constitutional and regulatory frameworks on such roles and then identifying the impact of the relationship of parliamentary institutions, governments and civil society on contemporary parliaments' new roles and the attempt of understanding the theoretical studies that defined the functions and roles of contemporary parliaments. In reality, constitutions and rules of procedure determine the powers of parliament and deal with the legislative role and supervisory tools. On the other hand, parliamentary practices provide new roles with political, economic, social, humanitarian and environmental dimensions, which do not depend only on legislative and supervisory jurisdiction but also on what are produced for such parliaments by national conditions.

\subsection{The subject significance}

The political landscape was complicated as a result of the impact of globalization and the needs of society were expanded to the extent that governments have become unable to meet them quickly. This opened the door to the parliamentary institutions to play new roles that should be considered. In addition, previous literature did not deal with the topic from the perspective of the ability of contemporary parliaments, as political institutions, to take over and assume new roles that were not previously defined or referred to through the inherited theories focusing only on the two functions of legislation and control. The idea of the new roles of contemporary parliaments has not been dealt with in an integrated manner by previous parliamentary studies, but in a separated manner. For instance, some previous literature focused on the parliamentary diplomacy, the role of parliament in fighting against corruption and their role in resolving domestic and international disputes. In other words, most previous literature focused on new roles of contemporary parliaments individually towards a specific activity and indicated that their roles are complementary to the works of the government and not regarded the parliamentary institutions as national sovereign parliaments and qualified to practice these roles. This gained the current study an additional importance.

Therefore, the researcher believes that the value of the study is that it is centered upon the new roles practiced by contemporary parliaments to solve social, economic, security, humanitarian, environmental and climatic issues as a representative political institution whose authority is derived from the people. These new roles are framed by the two constitutional and regulatory frameworks of parliament, in cooperation with the government and civil society. 
1.3.1 Parliamentary roles of modern legislatures (Blomgren and Rozenbery, 2012). This book explains that the concept of the roles of contemporary parliaments became more important and broader through which it is possible to understand contemporary political systems. The author has adopted the role theory to clarify parliamentary roles, demonstrating that parliamentary roles, particularly legislative and representative ones, are professional roles that provide a way to link the legislator to his institution. The study also has pointed out that the study of legislative roles is closely related to the modern analysis of legislative behavior, which provides deep theoretical insights on the motives and strategies of parliaments' members. This provides the possibility to understand the concept of parliamentary roles and to explain the attitude and behavior of a parliament's members towards an issue. It is based on several case studies including The Netherlands, Hungary, Australia, New Zealand, Britain and Austria. It also has examined the link between representative roles, different institutional conditions and parliamentary behavior, stressing that the roles played by deputies depend on those who believe that they should represent (their voters and party) and (their people their country). This gives rise to the conflict of loyalty, which must be considered without ignoring the social and political backgrounds of members as one of the determinants of the parliamentary roles. The study has defined the parliamentary roles as: "complex configurations and particular types of integrated goals, attitudes and behaviors that distinguish people in specific positions."

1.3.2 The new roles of parliamentary committees (Lawrence and Roger, 2005). This book focuses on the developments affecting the institutional structure of contemporary parliaments and their impact on the roles that such contemporary parliaments started to assume following the establishment of the parliamentary committees, which became the major center for parliamentary action. This helps the researcher in dealing with the structural and institutional aspects to recognize the new roles the contemporary parliaments have begun to perform especially through their committees and specifically after the spread of concepts of globalization and developments in the intellectual system of contemporary political systems and their focus on the spread of the idea of establishing parliaments and the expansion of their functions and roles both at the national or international levels. The book provides this research with new visions and trends of the roles of the parliamentary committees and tries to frame these roles.

1.3.3 Development of the relationship between parliament and civil society [...] civil parliament (Harouche, 2014). This study deals with the relationship between civil society and contemporary parliaments, its aspects and the best ways to activate it as one of the necessities of democratic life in societies. This study also handles the civil society's relationship with parliamentary committees and representatives and how those committees sometimes play the role of mediator between citizens and parliament. The study is useful to the researcher to answer the questions raised on the civil society's stance on the new roles played by contemporary parliaments. Then, it contributes to the creation of a perception of what parliament should do towards the civil society and what the civil society should do towards the parliament. The study also sheds light on civil society's vision of the new roles played by contemporary parliaments.

1.3.4 The internal system's role in the parliamentary work: an applied study on the work of the jordanian parliament (Abu Shamala, 2018). This study comes in line with the research's attempt to identify the constitutional and regulatory frameworks that allow contemporary parliaments to perform new roles. This helps in identifying the meaning of rules of procedure of the parliament and its constitutional frameworks, which directly affect 
the subject of the research. The study also clarifies the structure of the parliament and how it carries out its functions and new roles.

1.3.5 Functions and roles of parliament from a strategic perspective (Zarnouaa, 2017). The researcher has benefited from the new perspective and dimensions of the book, where the book compares, from a strategic perspective, between the functions and the roles played by contemporary parliaments. It explains how their traditional functions of legislation and control affect parliamentary work. The researcher benefited from the functions and missions of the parliament dealt with by the book. It indicates that Contemporary parliaments can help in creating and applying development plans. In addition, the book deals with some other news roles of contemporary parliaments, which are: safeguarding national security, maintaining social peace, protecting societies from internal conflicts and the role played by contemporary parliaments in information security and fighting against corruption. Therefore, this opens wider horizons for further studies about the new roles played by contemporary parliaments. In particular, the current research tries to shed light on how contemporary parliaments exercise their new roles.

1.3.6 Political and legal dimensions of Arab parliaments management: a comparative analytical study (Kasab, 2011). The researcher has benefited from this study with regard to the theoretical framework of the parliament's work and functions. It also proves useful in handling the political and legal frameworks represented by the constitution and the Arab parliaments' rules of procedure. The researcher has also benefited from the roles played by the parliament's bodies and its secretariat. The study shows the effect of the political environment of Arab countries on the works of parliaments, the influence of the executive authority, the weakness of multi-parties and the impact of corruption. This helps the researcher to know how to deal with these cases so as to determine the political and legal frameworks and to identify their new functions.

1.3.7 Non-Legislative powers of parliament (Ebeid and Aboud, 2017). The study has dealt with non-legislative jurisdictions, stressing the importance of such topics, which shed the light on the meaning of discretionary power enjoyed by the parliament and its members, in particular regarding powers granted in accordance with the two constitutional and regulatory frameworks. The study has tried to compare non-legislative terms of reference of parliament in Germany, Lebanon and Iraq. The researcher has benefited from this study because it shed light on the two constitutional and regulatory frameworks and their impact on new roles played by parliaments around the world.

1.3.8 Parliament's role in the development agenda: two case studies: Zambia and Tanzania (parliamentary union, September 2009). The issue of aid effectiveness is on top of the international policy's agenda where it is fundamental to achieve the millennium development goals aimed at eradicating abject poverty. This resulted in the establishment of the Development Cooperation Forum (DCF) of United Nations Economic and Social Council in 2007 to promote the implementation of the internationally-agreed development goals, including the millennium development goals. The Forum includes all major stakeholders, including national parliaments. It is held every two years to enhance the dialogue on the issues of policies regarding development. In response to these results and to promote the state's potential for development and poverty eradication, an Accra Action Plan was developed in 2008 with aim of encouraging donors to increase and accelerate aid, and reduce its terms. The Accra Plan stressed the important and crucial role of states' national parliaments in achieving development and eradicating poverty. It urges governments to cooperate with parliaments more closely in preparing, implementing and monitoring national development policies and plans. Hence, the role of parliamentarians, as representatives of the people, emerges where they speak on behalf of the poor and other 
vulnerable groups. They also ensure that development plans meet real priorities on the ground, the necessary legislations came into force, budget allocations were approved and that censorship on expenditures was imposed. The researcher believes that this study is of great importance because it clarifies contemporary parliaments' new roles in eradicating extreme poverty and improving health levels by studying two cases of Zambia and Tanzania, knowing how to provide assistance to parliaments of these countries and relationship of parliaments and government, civil society and other parliaments, and by clarifying the impact of the constitutional framework on the parliament's new roles.

\section{The conceptual framework}

The research clarifies the difference between roles and functions where there is a difference on the definition, practice and results of these roles and functions. Functions are tasks assigned to parliamentary institutions in accordance with predetermined legal rules of the constitution and the procedural system regulating the work of parliament. Roles; however, are the accumulation of the parliamentary performance of the institution as a whole or of representatives towards a specific issue for achieving a particular purpose (Al-Kubaisi and Qamber, 2001, p. 9). This purpose may not be one of the basic functions of the parliament such as humanitarian or environmental action. In a broader sense, in the framework of practicing the parliament's basic functions, sub-parliamentary activities can be integrated, leading to getting tangible results (Al-Sharqawi, 2007, p. 91).

Subsequently, roles are the political expression of the performance of functions, which required a specific meaning and sought to achieve lofty objectives (Anis et al., 2004, p. 520). Accordingly, new roles can be defined as:

"[...] any activity, role or mission undertaken by contemporary parliaments whose actions have impacts on society, state, or even the two regional and international levels, such as representative function, diplomatic function, making and approving public policy, combating corruption, reducing poverty levels, as well as limiting domestic disputes and societal conflicts (civil wars). On the other hand, traditional roles and functions are meant:" activities and missions that parliamentary institutions practiced and gained since their formation to date, namely the two legislation and control functions. The two functions are the oldest functions practiced by contemporary parliaments, which are the fundamental powers of the existence of parliamentary institutions around the globe".

Thus, it can be said that untraditional roles and functions practiced by contemporary parliaments are not mentioned in inherited classical theories of parliaments' functions. These theories did not explicitly refer to the concept of new roles. Indeed, many schools and writings dealt with the concept of new roles within the technical framework of the functions of contemporary parliaments. In fact, new roles previously were not elaborated and then they lost their importance whether in new or old democracies. Therefore, the current research tries to highlight the importance of new roles of contemporary parliaments by identifying new or unconventional roles, experiences and examples that illustrate how to practice these roles and knowing determinants through which these new roles can be practiced. Accordingly, it can be said that parliamentary responsibility is not limited, but rather it is constantly changing this change depends on the nature of the country and its political system, and the spread of concepts of democracy, freedom and civil society in it. These factors cast its shadow on the new functions and roles of parliament.

\section{Conventional roles and functions of parliamentary institutions}

The two legislation and control are the oldest functions that contemporary parliaments can undertake as one of the fundamental powers of parliamentary institutions around the world, 
not to mention what was addressed in most studies regarding the need to practice these functions and political mechanisms, which are regulated by the second function to reduce the authoritarianism and tyranny of governments. Therefore, the study will explain these functions briefly to differentiate between the two functions and new roles played by contemporary parliaments.

\subsection{Function of legislation}

It is the first function that was entrusted to parliamentary institutions to become the basic source of laws (Mill, 2017, p. 129). States' institutions specify the authority of legislation (parliament with its different names and types). Regardless of the source of legislation, whether was parliament or government, parliament is responsible for passing legislations governing states. These legislations are the origin and justification of creating parliaments (Hussein, 2015, p. 133). Legislation is one of the missions undertaken by parliament and then it passes laws on which the state's bodies depend in its all works and the state, for its part, abides by these laws.

\subsection{Function of oversight}

Parliament practices the oversight function on works undertaken by the government with the aim of showing and discussing such works publicly and also the accountability of the government. This leads sometimes to making parliamentary decisions on preventing the government from inappropriate actions or fall outside the framework of programs declared previously by the government. Thus, parliament undertakes these roles among what is called "the mechanisms of parliamentary oversight." This may give rise to a vote of no confidence in the government and replace it by another government, giving sufficient power for parliaments to ensure peoples' freedom (Mill, 2017, p. 131). In addition, the precise parliamentary oversight on the governments' actions is an indicator for good governance where parliament, by practicing this function, can achieve the balance of powers and protect the peoples' public interest.

\section{New roles of contemporary parliaments}

Recently, the functions and missions of governments considerably expanded by virtue of several factors, namely, globalizations, intertwining between internal and external relations, and the impact of technological developments (United Nations program in the Lebanese House of Representatives, August 2006). Consequently, contemporary parliaments' new roles enormously expanded to keep up with the expansion of their governments' functions. To perform these new roles, contemporary parliaments may adopt untraditional methods. Hence, the powers and roles of both legislative-executive authorities should be enshrined in the constitution. The constitutional legislator should take into account the resilience of the legislative and executive' powers and roles to keep pace with the repaid developments in all areas and accelerating issues that require rapid and appropriate procedures in a way that realizes the general interest of countries. For instance, contemporary parliaments interest in the sea and ocean issues between international conferences held by the international parliament and the United Nations to increase awareness of the dangers surrounding these issues (United Nations General Assembly, 2017). There are national experiences in this regard; for example, the Council of Moroccan Advisers, in partnership with the Grantham Institute for Climate Studies of London University and the Westminster Foundation for Democracy, adopted a program of the suitability of the national legislation system with the contents of Paris Agreement (The Council of Moroccan Advisers). The Maghreb council, as
New role of contemporary parliament 
a representative of the people, seeks to launch initiatives aimed at raising awareness of the sea and ocean' dangers, which can be applied in other national parliaments.

Accordingly, the roles of contemporary parliaments were no longer limited to legislation, enacting laws, monitoring the government and approving the general budget of the country. Rather, they are expanding their roles to include other missions based on the constitutional framework, the status and experience of the parliamentary institution and its ability to intervene in various local, regional and international issues. Contemporary parliaments' new missions are to obstruct ministerial amendments to exert pressure on governments, improve the conditions of minorities, amend political agreements, face external intervention or formulate foreign policy. For example, the essential role of parliament in the field of foreign relations is enshrined in the Danish constitution, which stipulated that "parliament shall appoint a committee for foreign affairs from among its members and the government shall consult this committee before taking any crucial decision on foreign policy (The Danish Constitution of 1955, Article 19, Paragraph 3). This confirms that some countries' constitutions attached great importance to new roles of contemporary parliaments. The Spanish constitution also gave the parliament the right to establish regions and ratify any change in the border of provinces and convert them into autonomous regions (The Spanish constitution, two Articles of 144/1 and 144), in accordance with the following:

- an autonomous community is permitted under the constitution; and

- the system of autonomy for regional parts, which are not included in the organization of governorates, is permitted.

The constitution gave parliament the right to exercise punitive authorities over all regions and administrative units of the state that may try to enjoy independence. For example, the Spanish parliament held many sessions on the Catalonia region's referendum conducted without the approval of central authorities and hosted concerned systems. Parliament practiced its powers according to Article (155) of the constitution by authorizing the central government to take deterrent procedures to prevent the Catalonia region from independence. Thus, the parliament's constitutional procedures maintained the country's unity. This confirms the parliament's exercise of new roles that have not been referred to in classical theories that made parliaments limited to the two legislative and supervisory functions.

The constitution, from which new roles of parliament emanate, complements the regulation of parliament. This regulation contains a set of rules and traditions adopted by parliament to regulate its work. The primary goal of the regulation is to provide freedom for deputies to discuss and report in an atmosphere of clarity and reassurance. The regulation includes the ways under which the work apparatus is composed and at the same time, it defines the principle of discussion and voting, the relationship between parliament and the government, how parliamentary committees, representatives and the General secretariat work, in addition to many tasks and roles that are not contained explicitly in constitutions or laws (The Arab Institute for Parliamentary Training and Legislative Studies, 2015, p. 2).

The interaction between the two constitutional and procedural frameworks provides contemporary parliaments with experiences and foundations that support the exercise of their new roles. In fact, given the diversity of their new roles, contemporary parliaments have been well received by the people, as their roles may be humanitarian, social, political, agricultural, environmental or climatic. Currently, the existence of parliament in countries is not a bone of contention and all countries hope that contemporary parliaments play a key role in promoting the principles of democracy, which cannot be applied without the parliament representing citizens and expressing their hopes and aspirations (Mahmoud and Abdel Rahman, 2015, p. 175). 
Accordingly, it can be said that the functions of parliaments of the world can be divided into: general functions and technical ones. General functions are called new roles, which are: participating in making public policy, helping in creating development plans, combating poverty and violence, parliamentary diplomacy and reducing the effects of natural phenomena. Technical functions are the two legislative and supervisory roles played by parliaments to face the executive authority (Al-Sawy, 2000, p. 56).

\section{Parliament's relationship with the government in light of contemporary changes}

The relationship between the legislative authority and the executive one takes several forms and patterns according to the system of government applied in each country (Abdel Khader, 2007, p. 14), which reflects the characteristics and features of the presidential, parliamentary or mixed system. Through this process, the relationship between the authorities is regulated by following several mechanisms: Firstly, the constitution, which determines a set of issues: the relationship between the three authorities, the constitutional amendment controls and procedures, and the rights and duties of citizens. Respecting the provisions of the constitution is a necessary condition to legitimize laws and judicial decisions and contemporary constitutions have thus established the relationship between the authorities. Secondly, the legislative law, which regulates the relationship between the two legislative and the executive authorities or regulates the relationship between the two councils as in several countries such as Algeria and Tunisia. Thirdly, establishing the ministry of parliaments to regulate the relationship between the two legislative and executive authorities. It can take several names such as a ministry of political and parliamentary affairs (Jordan), ministry of parliamentary affairs (Sudan) or ministry delegated by the government to regulate the relationship between parliament and civil society (Morocco). Fourthly, Regulating the relationship between the authorities in a way that combines the first and second methods or the first and third methods, to work out the best methods for enhancing cooperation, achieving the common good of the country and implementing the policy of separating the authorities according to both the environment and nature of the political system in the concerned country.

Despite the common characteristics of the relationship between the two executive and legislative authorities in the democratic countries, the new roles of the legislative authority vary, from one country to another, according to the relationship between the two authorities. For example, Ministers in parliamentary systems, in which the fate of governments remains contingent on the council's confidence and the evaluation of its performance, find themselves obliged to maintain good relations with the legislative authority despite the fact that a government has the ability to dissolve the parliament (Laver et al., 2008, p. 8), which called "flexible separation of powers." However, the presidential system such as the American system, where the president appoints his/her cabinet members and ministers do not need the confidence of the parliament, the relationship between the executive authority and the legislative one is highly competitive and conflicting, which is known as the "rigid separation of powers" (Dufarge, 2014, pp. 125-126).

There is no doubt that the new roles played by contemporary parliaments require these parliaments to develop and improve their performance in various fields and within different frameworks to have strong and independent stances against the executive authority, enter new spaces for the parliamentary work as a political institution and as individual members seeking to achieve gains for their constituents and achieve the representative, legislative and supervisory functions in parliament through the new roles that are used to achieve the desired objectives of the parliament's work. This proves that new roles are affected by the 
relation of the two parties and how to organize this relationship according to the type of adopted political system. This relationship is based on giving an opportunity for contemporary parliaments to practice and play new roles. In contrast, if the conflict between the government and parliament grew seriously hard, the government would seek to restrict these new roles by any means. For instance, the Supreme Court of the USA, in its decision on the case of McCulloch vs Maryland, states: "as long as the goals are legitimate, all means reached are also legitimate and are in conformity with professionalism and spirit of constitutional texts" (William and Alstyne, 1986, p. 58). The court referred to paragraph 1 of the constitution, under which Congress has the right to enact necessary laws that would enable it to practice its powers and referred also to Congress' new roles contained in paragraph 8 of the constitution (the USA' Constitution, Article 1). Thus, The USA Congress is based on the spirit of the constitution concerning the practice of such new roles, which significantly affected the course of events and crystallization of several attitudes.

\section{New roles in the framework of partnership with civil society}

The impact of the relationship between civil society and parliament on the new roles played by parliament cannot be ignored. There are many formulas for the participation of civil society in the work of parliament. The New Zealand Parliament, for instance, sends open invitations to receive feedback from citizens, individuals and organizations, through the press or other media, on specific topics. Some contemporary parliaments consider that civil or non-governmental organizations with specific interests are the appropriate bodies to benefit from their views on various issues. The Czech Parliament, on the other hand, holds what is usually known as "hearing sessions", which are some of the most common forms of civil participation. These sessions are devoted to listening to representatives of the civil and professional sectors concerned with the considered draft laws. The Turkish parliament has also entered into protracted negotiations with the civil society in Turkey on reconsidering the Penal Code in 2004 (Betham, 2006, pp. 95-96). Accordingly, new roles are to be practiced by cooperation between contemporary parliaments and civil society, whether through the joint cooperation, coordination and planning between them as in the first example or through pressure imposed by civil society on parliamentary institutions, which results in the engagement of civil society in the parliamentary action in specific and various issues as happened in Turkey's case.

\section{Constitutional and procedural determinants for activating new roles}

Some contemporary parliaments are playing roles in new unfamiliar areas that have not been discussed previously. In other words, they are playing new roles outside the framework of the constitution based on the powers delegated to these parliaments by the people. If national parliament is one of the political institutions of the state, its duties are to go beyond the provisions of the founding texts, in the sense that they have to work on developing frameworks that specify practicing new roles, taking into account the changing factors related to the basic idea behind its establishment. In contemporary politics, parliament is not just a legislative body in the constitutional structure of the parliamentary government that distinguishes most countries around the world and modern European-style democracies such as Australia, Canada and New Zealand. In addition, the constitutional source of governments is parliament. In fact, parliamentary elections at the national level are more interested in governments than selecting a group of representatives to deliberate and vote (Laver et al., 2008, p. 3).

However, some constitutions have given the parliament functions or missions that are basically outside the philosophical framework for the establishment of parliament, but have 
mixed them with the parliament's classic functions. The Egyptian constitution of 2014, for example, explicitly referred to the role of parliament in achieving social peace, guaranteeing the right of equality among citizens and preserving the rights of minorities within society by granting them the freedom of worship. It stresses the role played by the Egyptian Parliament in this area and obliges the Egyptian parliament to play new roles in achieving transitional justice, to ensure the disclosure of facts, hold accountable the wrongdoers and propose frameworks for national reconciliation through which the victims are compensated by following international standards. Therefore, the Egyptian Parliament has to pass laws that take into account the above-mentioned points. The Egyptian constitution mixes the new roles of the Parliament with its traditional legislative function, giving the parliament new roles and activities that were not found before.

In relation to the procedural framework (rules of procedure/internal order) of contemporary parliaments, have learned about the different ways and means of creating such a framework in the diversity of political systems and constitutions. However, what is agreed upon is the importance of this framework in parliamentary work, where in clarifies the functions and roles of contemporary parliaments and how they are exercised and interpret some constitutional articles in a manner consistent with such framework's vision for parliamentary action. Contemporary parliaments also provide parliamentary action with legitimacy and acceptability of the people, which is the basis of the delegated power of the legislative authority. It is known that the procedural framework of parliaments does not change on its own, but it is a reflection of internal and external interactions witnessed by parliamentary institutions. Consequently, they need to be adapted with such interactions by developing and amending the rules of the procedural framework to be in line with these interactions (Muller et al., 2009).

It should also be noted that some contemporary parliaments have an unusual power gained from the institution's rules of procedure that opens the door to new roles they perform through either the internal regulations or special law of the parliament, namely, the power to make decisions, which are morally and politically binding. In other words, such decisions could be guiding points, which are not necessarily adopted by the executive authority. However, these decisions may embarrass the government or may be binding by voting on them at the parliament. Consequently, the government becomes obligated to implement these decisions, which exposes it to accountability or voting of no confidence in the event that these decisions are not implemented by the government. The Iraqi Parliament's Resolution No. 20 of 2008, for example, stipulated that the Iraqi government should get foreign forces out of Iraq by July 13, 2009. This resolution directed the Iraqi government to take the necessary measures as soon as possible to remove the government forces by the deadline set by the Iraqi Parliament. This resolution became mandatory after the Iraqi Parliament had voted for it. In particular, it was passed by the legislative authority that has the popular will.

Thus, the parliament can sometimes direct the executive authority to take some actions with regard to particular topics in accordance with the recommendations of parliament, as the legislative authority is the authority representing the people.

Consequently, the presence of parliaments is no longer a bone of contention and, that is, why researchers currently focus on how to develop the functions of parliaments to play a fundamental role in the proper application of democratic principles, which cannot be applied without having a representative council to represent citizens and express their aspirations.

Thus, the procedural framework establishes new roles that may not be explicitly stipulated in the constitutional framework. Additionally, these new roles may establish or create areas that are not previously mentioned or stipulated. However, there are no 
constitutional or legal impediments to practicing and implementing such roles through the constitutional and legal frameworks. Additionally, contemporary parliaments' rules of procedure aim to organize and consolidate the functions and roles of parliaments and to show the importance of parliament in the political life of states and not to restrict its functions and roles. For example, New Zealand parliament's rules of procedure (2017) stipulated in Article 1:"the parliament's rules of procedure contains permanent orders and rules with aim of facilitating procedures inside the House of Representatives to practice its powers. Rules of the procedure is not intended to diminish or restrict rights, privileges, immunities and powers of the house."

Accordingly, constitutions' officials rules and parliaments' rules of procedure have become very important and influential in the attitudes and behavior of politicians, which significantly affects the practice of new roles (Muller and Saalfeld, 2013, p. 9), in addition to the interaction of the constitution with the parliaments' rules of procedure to create broader areas, though which contemporary parliaments can play new and influential roles in various fields that parliaments were not previously undertaken. Thus, in addition to their representative functions, contemporary parliaments began to monitor the financial performance of the government, assume some diplomatic roles and then play multiple roles based on the constitutional framework in the areas of national reconciliation, development, climate, policy-making, combating violence and other areas. In reality, parliaments have become one of the largest political institutions that have an impact on world events. For instance, the Turkish parliament rejected the government's request with regard to the entry of 62,000 US troops into Turkish territories to participate in Iraq's invasion (Saiegh, 2014, p. 2). This significantly affected the course of events during this period. This demonstrates that contemporary parliaments have taken the lead in bringing about national, regional and international changes.

Based on what was previously discussed, it is possible to discuss a broader example in the following sections, which is the role of the Iraqi parliament in meeting demonstrations' demands in Iraq started on October 1, 2019 to get acquainted with the most important new roles of the parliament.

\section{Iraqi parliament's traditional roles and functions}

\subsection{The legislative aspect}

Iraq's parliament has accelerated the process of considering several pending laws, including approving legislations on reconstruction law, the formation of the Federal services council, the independent electoral commission and the parliamentary election law, in addition to proposing amendments to some articles of the constitution. All, of these legislations came in response to demonstrators' demands.

\subsection{The supervisory aspect}

The Minster of Labor has been hosted by the government to consider the procedures of the emergency grant for the unemployed, widows and the divorced. Also, the security and defense committee hosted security leaders to know the circumstances of the demonstrators' exposure to violence by armed groups. The same committee was entrusted with supervising the development and implementation of security plans for the two governorates of "Najaf" ad "Thi Qar" in conjunction with security leaders.

\section{The new roles of Iraqi parliament}

\subsection{Parliamentary reforms package}

Mohamed Al-Halbousi, the speaker of Iraqi's parliament announced a package of parliamentary reforms to meet the demands of demonstrators, including the following: 
- The formation of a constitutional amendment committee, whose activities are to be concluded within 4 months.

- The dissolution of the councils of governorates, districts and sub-districtss.

- The selection of members of the Federal public service council [1].

- The legislation of the Construction council law.

- Stripping of the privileges of the three presidencies and senior officials of the state.

- Binding the government to immediately implement reforms and to enforce the laws of social justice.

- Follow-up the phases of implementing reforms proposed by the government.

- Immediately presenting significant laws by the government [2].

\subsection{Parliamentary decisions}

Parliamentary decisions are one of the tools that may lead to practicing the contemporary parliament of new roles. Regarding demonstrations, parliament take (nine) decisions during the period between October 10, 2019 until October 30,2019 [3] and it stressed not to use force against demonstrators. Consequently, weapons have been withdrawn from the security forces found in the protest areas, reducing the number of victims.

\subsection{Parliamentary statements}

Rules of procedure granted the parliament the right to make official statements, clarifying its positions on important and serious issues [4]. Thus, the parliament and deputies made several official statements calling for the resignation of the government, which constituted a form of official and popular pressure, leading to the resignation of the government, which is one of the most significant demands of demonstrators.

\subsection{Meeting parliamentary blocks with three presidencies}

Parliamentary blocks played a new role in achieving demonstrators' demands. This role is to hold meetings with three precedencies: the President of the Republic, the Prime Minister, the Head of the Judiciary, in addition to the Speaker of Parliament, giving rise to adopting mechanism for coordination between the three authorities and taking several parliamentary and governmental decisions with the aim of knowing the reasons for demonstrations and finding ways to solve. Consequently, more than five meetings with the speaker of the parliament have been held and more than three meetings with the President of the republic since October 1, 2019 [5].

\subsection{Parliamentary committees}

The role of these committees was to monitor the events of demonstrations, for example, the parliamentary security and defense committee, in coordination with the parliament, hosted security leaders to find out the reasons for the increasing number of victims and the high rates of violence against demonstrators. In addition, the parliamentary human rights committee, in coordination with the commission of human rights, made reports continously [6] on cases of assaults on demonstrators, met with protestors and put pressure on competent authorities to release detainees [7]. It is important to say that these new roles of the parliament are an extension of its supervisory role representing in follow-up and supervision governmental procedures and making reports about them. At the same time, these new roles played by the parliament leads to meeting demonstrators' demands. 


\section{Relationship of Iraqi parliament with the government in light of the events of demonstrations}

The relationship between the government and parliament is characterized by the agreement at one time and disagreement at other times. The parliament presented its reformist package, which the government considered it interference in its exclusive powers, particularly with regard to achieving social justice, the parliament's insistence on immediately meeting demonstrators' demands and stripping of government officials' privileges. Simultaneously, the relationship between them saw periods of harmony, for example, the government-held three prolonged meetings with the speaker of parliament and the political blocs to consider finding the best way to achieve the demands of demonstrators and solve the crisis. However, the relationship between them became strained after the use of excessive violence by the government against demonstrators. This prompted the government to submit its resignation to parliament, which accepted the resignation after unanimously voting. In fact, the Iraqi constitution has been devoid of the text on the resignation of the government, but parliament, which has the popular will and delegates the government, addressed the issue of the constitutional vacuum by presenting the resignation to deputies to vote. This makes this practice a precedent that falls within new political norms in the Iraqi' political system. Thus, the parliament played a new role in creating new political norms within the entire political system.

\section{New roles in the framework of partnership with civil society}

The parliament adopted new procedures for the first time where it hosted demonstrators inside the parliament in cooperation with unions and civil society with the aim of finding fast solution to them. After the expansion of demonstrations to include most of the governorates, a new procedure has been adopted by the parliament by sending deputies to the areas of demonstrations to meet with demonstrators. Also, the speaker of the parliament participated with a number of deputies in demonstrations to give demonstrators momentum to meet their demands and, the deputies of "revolutionaries block" held a sit-in inside the parliament headquarters as an expression of support for demonstrations [8].

\section{The effect of constitutional and procedural determinants on the parliament's new roles}

The 2005 constitution confirmed that the Iraqi political system is parliamentary (Salman, 2012, p. 231). The constitution gave the parliament powers that could constitute a serious impediment to the Cabinet. Therefore, the parliament dominated the Cabinet. Additionally, the constitution provided the parliament with a constitutional and political advantage that the President does not have (Gaber, 2015, p. 281). Article (61/3) of the constitution stipulates that the parliament is the source of powers and has the popular will, which qualifies it to play new roles outside the framework of traditional jobs. The constitution also gave the parliament, according to Article (51), freedom to draft its rules of procedure, without the intervention of any party, with the aim of regulating its duties and functions, in addition to activities it undertakes in accordance with the perspectives of the deputies of the parliament and political blocs. Consequently, such powers enable the parliament to add articles and texts to its procedural framework that allow it to practice new roles that were not previously contained in the constitution. To solve the crisis of demonstrations, the parliament has formed a high committee to consider the demands of demonstrators and take political and legislative measures to meet them. The high committee consists of four permanent committees, namely, legal, financial, human rights and service and reconstruction. These committees aim to meet demonstrators' demands in the form of legal legislations and add 
these legislations to the proposal of laws coming from the government. Although there is no explicit text in the Iraqi constitution indicating the authority of parliament to form subcommittees or investigative committees, the rules of procedure provided such committees with the legal basis, as parliament gave itself the right to form them [9].

New role of contemporary parliament

\section{Research findings and recommendations}

\subsection{Research findings}

This study has concluded that contemporary parliaments can play new roles in various fields, whether internal or external and in different sectors as well, whether humanitarian, environmental, service or climatic, as a result of the great developments and complexities occurred around the world. Such developments and complexities have cast a shadow on governments and affected their abilities in dealing with the issues immediately because of enormous challenges in addition to ongoing developments of parliamentary institutions' action in the world, at the technical level of the departments and secretariats of contemporary parliaments or members of Parliament and the institution as a whole. Although the concepts of parliamentary roles have been affected by changes in the social and economic background of deputies and their political socialization and personality (Muller and Saalfeld, 2013, p. 8), the interaction of contemporary parliaments, governments and civil society cast its shadow on the practice and efficiency of new roles.

\subsection{Recommendations}

The most important recommendations that can be reached in this study are the need for the contemporary parliaments, especially the Arab ones, to work on developing their constitutional and procedural frameworks to keep up with accelerating events, meet the demands of the peoples and help to rid their countries of many phenomena that require an immediate intervention. As a result, governments are sometimes in critical situations because of the increasing complexity of life and the need for solutions that are in the hands of the legislative authority. In addition, this study recommends the development of Arab parliamentary institutions to improve their professional performance as representatives of the people and work to increase their interaction with the civil society to provide them with new and direct information on the issues they are interested in so as to find the best ways to deal with them. Moreover, the Arab parliamentary institutions need to cooperate with the executive authorities in the areas that need fundamental and satisfactory solutions for all parties to achieve stability and development. Contemporary parliaments can address matters that were neglected by the constitution. In addition, the researcher sees that it is necessary to open the door for cooperation with international organizations with the aim of succeeding new roles of contemporary parliaments. In essence, such organizations have the ability to provide financial and technical support for parliaments to achieve their objectives.

\section{Notes}

1. The researcher interviewed with Mrs Dr Mayada Al-Hajjami, the director general of the parliamentary research committee of the Iraqi parliament on December 5, 2019.

2. The researcher interviewed with Mr Haider Jasim Muthanna, the director general of the parliamentary committee of the Iraqi parliament on November 22, 2019.

3. Iraq's council of representatives, general security secretariat, parliamentary committee, committees affaris department. resolution No. (3) of October 10, 2019 sent to the Prime Minister's office, numbered 1/9/10868, in addition to a photocopy of parliamentary decisions No. 5, 6, 7, 8, 9, 11 sent 
to the office of the president of the Republic, No. 1/9/11524, dated October 31, 2019, the internal system of the Iraqi parliament, Article (38).

4. Iraqi parliament's rules of procedure, Article (38).

5. An interview with Mr Ahmed Saad, the head of the committee department of Iraqi parliament on December 9, 2019.

6. An interview with the head of the parliamentary human rights committee of the Iraqi parliament, dated December 11, 2019.

7. Report of the parliamentary human rights committee on demonstrations in Iraq in the period from October 1, 2019 to November 10, 2019, p. 3.

8. An interview with the deputy of the Iraqi' parliament, Ahmed Al-Mashadani on December 10, 2019.

9. The rules of procedure of Iraqi parliament, Article (82).

\section{References}

Abdel Khader, A. (2007), "Lectures on comparative political systems", Faculty of Law and Political Science, Saida University, Algeria.

Abu Shamala, F. (2018), The Role of the Internal System in Parliamentary Work: An Empirical Study on the Work of Jordanian Council of Representatives, Dar Al- Khaleej for Publishing and Distribution, Jordan.

Al-Hendaoi, G. (2010), The Constitutional Law and Political Systems, Al- Aeref for Publishing, Beirut.

Al-Kubaisi, A.G. and Qamber, M.M. (2001), The Role of Higher Education Institutions in the Economic Development of Society, Dar Al- Thaqafa for Printing, Publishing and Distribution, Doha.

Al-Sawy, A. (2000), The Future of Parliament in the Arab World, Dar Al-Nahda Al- Arabia, Cairo.

Al-Sharqawi, S. (2007), Political Systems in the Contemporary World, Dar Al- Nahda Al-Arabia, Cairo.

Anis et al. (2004), The Medieval Dictionary, Dar Al-Shurooq Al-Dawlia, Cairo.

Betham, D. (2006), "Parliament and democracy in the 21st century: good practice guide, international parliamentary union".

Blomgren, M. and Rozenbery, O. (Eds), (2012), Parliamentary Roles in Modern Legislatures, Frank Cass and Company Limited, Routledge, United Kingdom, London.

Dufarge, M. (2014), Political Institutions and Constitutional Law: Major Political Systems, University Institution for studies and Publication (Majd), Beirut.

Ebeid, A. and Aboud, S. (2017), "Non legislative powers of parliament", Al-Mohakek Journal for Legal and Political Science, No. 1.

El-Menoufi, K. (1987), The Origins of Comparative Political Systems, El- Robein for Publishing and Distribution, Kuwait.

Gaber, A. (2015), "The problematic of the parliamentary political system in the permanent constitution of the republic of Iraq", Dersat Dawlia Journal, Baghdad University, Center for Strategic and International Studies, No. 63.

Harouche, N. (2014), "The development of parliament's relationship with civil society", Al-Fikr Journal, No. 10.

Hussein, M.T. (2015), "Justifications of the existence of the parliament", Journal of Al-Kofa for Legal and Political Sciences, Vol. 1 No. 25.

Kasab, Y.F.A. (2011), "The political and legal dimensions of arab parliaments management: a comparative analytical study", Unpublished Doctorate dissertation, Faculty of Economics and Political Science, Cairo University, Cairo.

Laver, M., Weingast, B. and Wittman, D. (Eds.) (2008), Legislatures and Parliaments in Comparative Politics Context, Oxford Handbook of Political Economy, Oxford University Press. 
Lawrence, D.L. and Roger, H.D. (2005), The New Roles of Parliamentary Committees, Routledge, London.

Mahmoud, S.K. and Abdel Rahman, S.S. (2015), "The necessity of the dual federal and legislative in Iraq and the constraints of its formation", Journal of the Faculty of Law for Legal and Political Sciences, Karkuk University, Iraq, Vol. 4 No. 14.

Mill, J.S. (2017), Parliamentary Governments, Al-Ghori, E. (Trans.), Al-Arabi Center for Research and Policies Study, Beirut.

Muller, W. and Saalfeld, T. (2013), Member of Parliament in Western Europe: Roles and Behavior, Routledge, New York, NY.

Muller, W. Sieberer, U. and Bechers, M. (2009), "Engineering parliamentary rules: a theoretical framework and macro patterns in the 20th European democracies", available at: https://ecpr.eu/Filestore/ paperproposal/799aa3F3-c.583-4a96-a50e-0480aff346c7.pdf (accessed 3 September 2019).

Saiegh, S. (2014), "Law making", The Oxford Handbook of Legislative Studies, doi: 10.1093/oxfordhb/ 97801996530/0.013.0012, available at: http://pages.ucsd.edu/ssaiegn/chapter_oxford.pdf

Salman, S.D. (2012), "Parliamentary powers in the 2005 Iraqi constitution", Al- Sayisa Al-Dawlia Journal, Al-Mustanisiriya University, Iraq, No. 21.

The Arab Institute for Parliamentary Training and Legislative Studies (2015), "The path of the legislative process of the lebanese parliament".

United Nations General Assembly (2017), "A brief report of the 2017 parliamentary meeting on oceans and the law of the sea, the number of the document a/71/898".

William, W. and Alstyne, V. (1986), "Implied powers", Society Journal, Vol. 24 No. 24, available at: https:/link.spriner.com/article/10.1007/BF02695939 (accessed 20 August 2019).

Yemeni Parliament Observatory (2014), Parliament Adopts Initiative for national Reconciliation and rejects Foreign Intervention, A Report available at: www.ypwatch.org (accessed 10 December 2017).

Zarnouaa, S.S. (2017), The Functions of Parliament and Its Role from a Strategic Perspective, Scientific Center for Political Studies, Amman.

\section{Further reading}

Al-Qasabi, R.A. (2007), Research Curricula in Political Science, Faculty of Economics and Political Science, Cairo University, Cairo.

Constitution of the Arab Republic of Egypt (2014), "Articles 235 and 241".

Council of Moroccan Advisers "Call on national parliaments to take tangible initiatives with aim of increasing awareness of threats to the seas and oceans", available at: www.Chambredesconseillers

Darwish, M.M. (2018), Research Methods in Human Sciences, Institution of Arab Nation for Publishing and Distribution, Egypt.

El-Menofy, K. (2009), Introduction to Curricula and Research Methods in Political Science, Cairo University, Cairo.

Soliman, A.S. (2014), Research Methods, Aalam Al- Kotob, Cairo.

United Nations Program in the Lebanese House of Representatives (2006), "Parliamentary control over the executive authority, series of studies and information, the 11th file".

\section{Corresponding author}

Haider Muthnna Almoatasm can be contacted at: haider_muthanna@yahoo.com

For instructions on how to order reprints of this article, please visit our website:

www.emeraldgrouppublishing.com/licensing/reprints.htm

Or contact us for further details: permissions@emeraldinsight.com

\section{New role of contemporary parliament}

